that the main part of the conference will be made up by contributions from scientific men and editors of scientific journals at Cambridge. It is also hoped that the indexing of scientific information will be discussed.

\section{Examinations in Secondary Schools}

$I_{N}$ its report on "Examinations in Secondary Schools" the Secondary School Examinations Council, which was reconstituted in June 1946 and asked to advise the Minister of Education on the future of examinations in secondary schools, recommends the complete revision of the present examination system. It suggests that the School Certificate and Higher School Certificate examinations should be replaced in 1950 by a single external examination which would be open both to pupils over sixteen years of age on September 1 in any given year and to candidates over that age who are no longer in attendance at a secondary school. In reaching this conclusion the Council has been influenced by the consideration that an external examination is only profitable and proper for $(a)$ those who wish to compete for scholarships or similar awards at universities or comparable establishments of further education, and $(b)$ those who have followed courses substantially beyond the compulsory school age and who wish to establish competence in certain subjects in order to secure exemption from university or professional examinations. The Council proposes that papers in the new external examination should be set at three levelsordinary, advanced and scholarship. The ordinary papers would be designed to provide a reasonable test in subjects which a student has taken as part of a wide general course to the age of sixteen, the advanced to test the ability of pupils in subjects which have been pursued for two years as specialist studies in a sixth form, and the scholarship to give specially gifted pupils an opportunity to show distinctive merit and promise. Successful candidates would receive a "General Certificate of Education" recording the subjects in which they had passed and the level at which they had been successful.

To supplement the information provided by the "General Certificate of Education" and to provide pupils who leave school before attaining the age of sixteen with a record of attainment, the Council also recommends that "every pupil on leaving a secondary school should be provided with a comprehensive school report containing the fullest possible information about him and his abilities and potentialities". These reports would include the results of systematic and varied internal examinations, both formal and iess formal, and of objective tests which "should be set periodically within the secondary school". In publishing these recommendations the Minister of Education endorses the hope expressed by the Secondary School Examinations Council that the widest possible opportunity will be given for the discussion of the recommendations before any detailed decisions are taken on them.

\section{Gazetteer of Great Britain}

A RECENT publication of the Ordnance Survey is a fifty-page gazetteer of Great Britain (Southampton : Ordnance Survey Office, 1946. 5s.). It is in two sections: England and Wales, and Scotland. Each section is followed by an index diagram which shows in red the sheet lines and numbers of the One-Inch Popular Edition and in green the sheet lines and numbers of the Quarter-Inch map. The skeleton outline of the counties and the lines of the National Grid are shown in grey. Towns and chief villages only appear in the gazetteer, which gives for each the National Grid reference.

\section{Phenazines and Benzcinnolines: a Correction}

P. Z. and R. Slack write: "We wish to correct an error in our communication on 'Phenazines and Benzcinnolines' (Nature, Sept. 27, p. 437). The 3 : 4-benzcinnoline obtained melted at $154-155^{\circ}$, agreeing, in fact, with the literature. Our quoted figure referred to a specimen of carbazole obtained from the same reaction using modified conditions which will be reported as soon as possible in the full publication. Complete analytical figures for the dipicrate mentioned in our communication are: Found, $\mathrm{C}, 45 \cdot 0 ; \mathrm{H}, 2 \cdot 0 ; \mathrm{N}, 17 \cdot 7 . \quad \mathrm{C}_{12} \mathrm{H}_{8} \mathrm{~N}_{2}$ $2 \mathrm{C}_{6} \mathrm{H}_{3} \mathrm{O}_{7} \mathrm{~N}_{3}$ requires $\mathrm{C}, 45 \cdot 1 ; \mathrm{H}, 2 \cdot 2 ; \mathrm{N}, 17 \cdot 6$ per cent."

\section{Announcements}

ThE Rockefeller Foundation has made a further grant of 85,000 dollars to the University of Leeds in support of the investigations of Prof. W. T. Astbury into the molecular structure of biological tissues.

THE United Kingdom delegation to the second general conference of Unesco, which opens in Mexico City on November 6, will consist of Mr. D. R. Hardman, Parliamentary Secretary, Ministry of Education; Sir Ronald Adam, chairman of the British Council ; Sir Henry French, director-general, British Film Producers' Association; Mr. J. B. Priestley; and Prof. E. D. Adrian. The alternate delegates are Sir John Maud, permanent secretary, Ministry of Education; Mr. Ronald Gould, general secretary, National Union of Teachers; Sir John Forsdyke, director and principal librarian, British Museum ; Dr. Margaret Read, University of London ; Dr. W. P. Alexander, secretary, Association of Education Committees.

AT the annual general meeting of the Irish Chemical Association the following officers and council were elected for the 1947-48 session: President, Prof. T. S. Wheeler; Vice-President, Prof. E. J. Conway ; Hon. Secretary, G. F. O'Sullivan; Hon. Treasurer, J. Belton; Council, Dr. V. C. Barry, T. W. Breaden, D. Crowley, B. G. Fagan, Miss M. MacNeill, N. V. Nowlan, D. O'Tuama. Prof. T. S. Wheeler will deliver his presidential address on "A New Aspect of the Claisen Condensation" in the Department of Chemistry, Seience Buildings, Upper Merrion Street, Dublin, on October 22 at 7.30 p.m.

UnIVERsity College LondoN, and the British Boot, Shoe and Allied Trades Research Association jointly are offering a research fellowship (annual value about $£ 650$ ), tenable in the first instance for two years, for work on the structure of the human foot, its mechanics and the mechanics of human locomotion. The work will be done in the Department of Anatomy, University College London, under the immediate direction of Dr. W. A. Fell, and in close liaison with the Research Association's headquarters and laboratories in Kettering, Northamptonshire. Applications from persons with medical or biological qualifications should be sent before December 31 to the Secretary, University College London, Gower Street, W.C.I, or to the Director of Research, Satra House, Rockingham Road, Kettering. 